\title{
SUPLEMENTAÇÃO COM LEVEDURA DE CRÔMIO ELEVA A CONCENTRAÇÃO SÉRICA DE CRÔMIO EM BOVINOS
}

\author{
SUPPLEMENTATION WITH CHROMIUM YEAST INCREASE SERUM CONCENTRATION \\ OF CHROMIUM IN CATTLE
}

\author{
Giometti, J. ${ }^{1 *}$, Chiacchio, S.B. ${ }^{2}$, Albas, A. ${ }^{3}$, Pardo, P.E. ${ }^{1}$, Bremer Neto, H. ${ }^{1}$, Giometti, A.I. ${ }^{1}$ \\ e Reis, L.S.L.S. ${ }^{2}$
}

\begin{abstract}
${ }^{1}$ Universidade do Oeste Paulista. UNOESTE. Presidente Prudente. Brasil.
*centraldepesquisaepublicacoes@yahoo.com.br

2Universidade Estadual Paulista Júlio de Mesquita Filho-UNESP. Faculdade de Medicina Veterinária e Zootecnia. Botucatu. Brasil.

${ }^{3}$ Pólo Regional de Desenvolvimento Tecnológico dos Agronegócios da Alta Sorocabana. Presidente Prudente. Brasil.
\end{abstract}

\section{Palavras chave adicionais}

Suplementação mineral.

\section{RESUMO}

O estudo avaliou o efeito da suplementação com doses crescentes de crômio/dia sobre a concentração sérica de $\mathrm{Cr}$ em bovinos. Sessenta novilhas da raça Nelore com idade entre 2 e 5 anos foram distribuídas aleatoriamente em 4 grupos ( 15 novilhas/grupo) alimentadas com pastagem de Brachiaria decumbens não fertilizada. No grupo controle (Gc), as novilhas receberam mistura mineral sem adição de $\mathrm{Cr}$. Nos demais as novilhas receberam 0,59; 1,19 e 2,38 $\mathrm{mg} \mathrm{de} \mathrm{Cr}^{+3} /$ animal/dia (grupos $\mathrm{G}_{8.5}, \mathrm{G}_{17} \mathrm{eG}_{34}$, respectivamente). Colheramse amostras de sangue nos dias 0,30 e 60 . A concentração sérica de crômio foi determinada por meio de espectrofotometria de absorção atômica com forno de grafite. A fonte de crômio utilizada foi a levedura de crômio. Os resultados mostram que não houve diferença significativa $(p>0,05)$ na concentração sérica de crômio das novilhas entre os grupos $\mathrm{Gc}_{3} \mathrm{G}_{8,5} ; \mathrm{G}_{17}$ e $\mathrm{G}_{34}$, num mesmo dia de observação. O único efeito observado foi do tempo de suplementação com crômio no o grupo $G_{34}$. Neste grupo a concentração sérica de crômio apresentou aumento significativo $(p<0,05) 60$ dias após o início da suplementação. Conclui-se a levedura de $\mathrm{Cr}$ pode ser utilizada como fonte deste elemento mineral para os bovinos e a suplementação com $2,38 \mathrm{mg} /$ bovino/dia foi a dose que mais elevou a concentração sérica de

Recibido: 19-10-08. Aceptado: 24-2-10.

\section{AdDitional KeYWORdS}

Mineral supplementation.

$\mathrm{Cr}$ nos bovinos da raça Nelore durante o período experimental.

\section{SUMMARY}

This study evaluated the effect of daily chromium supplementation at growing doses on serum $\mathrm{Cr}$ levels in cattle. Sixty Nellore heifers 2 to 5 years old were randomly assigned to one of four groups (15 heifers/group) fed non-fertilized Brachiaria decumbens pasture. In the control group (Gc), the heifers received a mineral mixture without $\mathrm{Cr}$. In the other groups, heifers received $0.59,1.19$ or $2.38 \mathrm{mg} \mathrm{Cr}^{+3} /$ animal/day, groups $\mathrm{G}_{8.5}$, $G_{17}$ and $G_{34}$, respectively. Blood samples were collected on days 0,30 and 60 . Serum concentration of chromium was determined by graphite furnace atomic absorption spectrophotometer. The chromium source used was the chromium yeast. The results do not support any significant difference ( $p>0.05)$ among serum chromium levels of heifers in groups $\mathrm{Gc}, \mathrm{G}_{8.5}, \mathrm{G}_{17}$ and $\mathrm{G}_{34}$ at a same observation day. Only effect of supplementation time was detected in group $G_{34}$. In this group there was significant increase $(p<0,05)$ in the concentration serum chromium 60 days after the beginning of the experiment. Concluded $\mathrm{Cr}$ yeast can be used as the source of this mineral element 
for animals and supplementation with $2.38 \mathrm{mg} /$ cattle/day was the dose that most increased the serum concentration of $\mathrm{Cr}$ in Nellore cattle during the experimental period.

\section{INTRODUÇÃO}

O crômio é um microelemento mineral essencial que está presente nos tecidos dos animais na forma de molécula organometálica, chamado de fator de intolerância à glicose. Este potencializa a ação da insulina (Bryan et al., 2004) promovendo o processo anabólico e inibindo o catabólico nos músculos, fígado e também no tecido adiposo. Além disso, eleva a taxa de crescimento (Hayirli et al., 2001) e o ganho de peso (Carvalho et al., 2003), reduz a incidência de retenção de placenta (Bryan et al., 2004) e de cetose (Carvalho et al., 2003), além aumentar a resposta imune humoral tornando os animais mais resistentes às doenças infecciosas (Giometti et al., 2006). No entanto, o National Reserch Council - NRC (1996) relata que as informações ainda não são suficientes para determinar o requerimento deste mineral em bovinos. Portanto, neste estudo avaliaram-se os efeitos de diferentes concentrações de Crorgânico adicionadas na mistura mineral sobre a concentração sérica de $\mathrm{Cr}$ em bovinos.

\section{MATERIALEMÉTODOS}

O experimento foi realizado no município de Mirante do Paranapanema-SP, entre os meses de agosto a dezembro.

Utilizaram-se 60 novilhas da raça Nelore com aproximadamente 2 a 5 anos de idade, com peso vivo médio de $300 \mathrm{~kg}$, alimentadas com Brachiaria decumbens, em sistema extensivo. Os animais foram aleatoriamente distribuídos em quatro grupos experimentais com fornecimento da mistura mineral de forma ad libidum (15 novilhas/grupo): um grupo controle com mistura mineral sem crômio e grupos suplementados com mistura mineral contendo 8,$5 ; 17$ e $34 \mathrm{mg}$ de $\mathrm{Cr} / \mathrm{kg}$ de suplemento, caracterizando os grupos experimentais. O consumo diário médio/ animal foi de $70 \mathrm{~g}$ da mistura mineral (obtido em período imediatamente anterior ao experimental), de onde se determina que no período experimental os animais consumiram 0,$0 ; 0,59 ; 1,19$ e $2,38 \mathrm{mg} \mathrm{de} \mathrm{Cr} / \mathrm{dia}$, respectivamente. Assim, os grupos experimentais foram denominados $\mathrm{Gc}, \mathrm{G}_{8,5} ; \mathrm{G}_{17}$ e $\mathrm{G}_{34}$, respectivamente.

Após 30 dias de ajuste ao novo suplemento mineral e condições de manutenção, iniciou-se o período de observação experimental, que durou 60 dias.

O suplemento mineral utilizado foi produzida por Fort Sal Suplementos Mineral Ltda que foi adicionado com 0; 8,5; 17 e $34 \mathrm{mg}$ de $\mathrm{Cr} / \mathrm{kg}$ de suplemento. Todos os suplementos foram fornecidos aos animais de forma ad libidum em cocho de madeira coberto, com 13 centímetros lineares por animal.

A fonte de crômio utilizada foi produzido por Alltech do Brasil, composto por Saccharomyces cerevisae, linhagem YeaSacc 1026 , contendo $1,0 \mathrm{~g}$ de $\mathrm{Cr}^{3+} / \mathrm{kg}$ de produto.

Os quatro piquetes utilizados pelos bovinos dos grupos $\mathrm{Gc}, \mathrm{G}_{8,5}, \mathrm{G}_{17}$ e $\mathrm{G}_{34}$ eram semelhantes na topografia, composição botânica e sem fertilização, sendo formados por Brachiaria decumbens. No $1^{\circ}$ dia do experimento, colheram-se amostras das forrageiras dos pastos, cortadas à altura de pastejo (20 $\mathrm{cm}$ do solo) e posteriormente conservadas sob refrigeração $\left(-5^{\circ} \mathrm{C}\right)$ até a realização da determinação da concentração de Cr.

As amostras de sangue dos bovinos foram colhidas nos dias $0,30,60$, por meio da punção da veia jugular em tubos à vácuo de $10 \mathrm{ml} \mathrm{sem}$ anticoagulante e centrifugados a 2500 rpm por 10 minutos. Então as amostras de soro foram armazenadas a $-20^{\circ} \mathrm{C}$ para posterior determinação da concentração sérica de $\mathrm{Cr}$.

A concentração de $\mathrm{Cr}$ na Brachiaria decumbens dos piquetes e no soro sanguíneo dos bovinos foi determinada por meio 
da técnica de espectrofotometria de absorção atômica com forno de grafite.

Para saber se a suplementação com $\mathrm{Cr}$ influenciou a concentração sérica de $\mathrm{Cr}$ realizaram-se os seguintes procedimentos estatísticos: 1) teste de normalidade para todos os grupos; 2) aplicação da análise de variância de Friedman nos dados originais, uma vez que os dados apresentaram distribuição não normal. Por fim, aplicara-se o pos hoc (Nemenyi test) a fim de saber qual(is) suplementação(ões) alimentar com $\mathrm{Cr}$ provocou diferenças nas concentrações séricas de $\operatorname{Cr}$ (Zar, 1999).

\section{RESULTADOSEDISCUSSÃO}

A igualdade de pastejo ficou comprovada pela semelhança na concentração de crômio presente na forragem (Brachiaria decumbens $)$ de ambos os piquetes $(0,05 \mu \mathrm{g}$ de $\mathrm{Cr} / \mathrm{g}$ de matéria seca) e que estas forrageiras eram deficientes neste mineral conforme preconizado pelo NRC (1996) relata que a dieta dos bovinos deve conter de 0,79 a 1,60 mg de $\mathrm{Cr} / \mathrm{kg}$ de matéria seca. Além disso, no dia zero, as concentrações séricas de crômio das novilhas de ambos os grupos experimentais estavam dentro da normalidade (tabela I) conforme preconizado por
Mordenti et al. (1997) relatam que o valor médio da concentração sanguínea de crômio varia de 5 e $50 \mathrm{ppb}$. Assim os resultados obtidos da concentração sérica de $\mathrm{Cr}$ das novilhas em ambos os grupos durante o período experimental foram exclusivamente em função dos tratamentos.

Na tabela I observa-se que não houve diferença significativa ( $p>0,05)$ na concentração sérica de crômio das novilhas que recebram suplemento mineral com ou sem crômio, grupos $\mathrm{G}_{8,5}, \mathrm{G}_{17}, \mathrm{G}_{34}$ e Gc; respectivamente. No entanto, houve efeito do tempo de suplementação com crômio. Observa-se que o grupo $\mathrm{G}_{34}$ teve aumento significativo na concentração sérica de crômio no dia 60 $(\mathrm{p}<0,05)$. Assim, a suplementação com 2,38 $\mathrm{mg}$ de $\mathrm{Cr} /$ novilha/dia e a levedura de crômio mostrou-se eficaz para suplemetar dos bovinos da raça Nelore como meio de prevenir a correncia da deficiência deste elemento mineral. Entretanto, as suplementações com $0,59 \mathrm{mg}$ e $1,19 \mathrm{mg}$ de crômio/novilha/dia não interferiram significativamente na concentração sérica de crômio das novilhas, desta forma, provavelmente estas concentrações de crômio orgâncico foram insufientes e são indesejáveis para suplementar os bovinos da raça Nelore.

Os resultados obtidos demonstraram que

Tabela I. Efeito da suplementação com $0(G c), 0,59\left(G_{8.5}\right), 1,19\left(G_{12}\right)$ e 2,38 $\left(G_{3,}\right) \mathrm{mg}$ de $\mathrm{Cr} /$ bovino/dia na concentração sérica de crômio (ppb) de novilhas ( \pm desvio padrão). (Effect of supplementation with $0(\mathrm{Gc}), 0.59\left(\mathrm{G}_{8,5}\right), 1.19\left(\mathrm{G}_{17}\right)$ and $2.38\left(\mathrm{G}_{34}\right) \mathrm{mg} \mathrm{Cr} /$ bovine/day in serum concentration of chromium (ppb) of heifers $( \pm S D)$ ).

\begin{tabular}{|c|c|c|c|}
\hline $\begin{array}{c}\text { Grupos } \\
\text { de bovinos }\end{array}$ & \multicolumn{3}{|c|}{$\begin{array}{c}\text { Concentração sérica de crômio (ppb) } \\
\text { Dias de observação }\end{array}$} \\
\hline $\mathrm{Gc}$ & $10,11^{\mathrm{Aa}} \pm 1,59$ & $11,77^{A a} \pm 0,50$ & $12,46^{\mathrm{Aa}} \pm 0,24$ \\
\hline $\mathrm{G}_{8,5}$ & $11,24^{\mathrm{Aa}} \pm 2,28$ & $11,71^{\mathrm{Aa}} \pm 0,43$ & $12,52^{\mathrm{Aa}} \pm 0,30$ \\
\hline $\mathrm{G}_{17}$ & $9,70^{\mathrm{Aa}} \pm 2,52$ & $11,87^{\mathrm{Aa}} \pm 0,39$ & $14,27^{\mathrm{Aa}} \pm 2,97$ \\
\hline $\mathrm{G}_{34}$ & $9,30^{\mathrm{Aa}} \pm 2,70$ & $12,62^{\mathrm{Aab}} \pm 0,72$ & $18,96^{\mathrm{Ab}} \pm 3,67$ \\
\hline \multicolumn{4}{|c|}{$\begin{array}{l}\text { Nas colunas, letras maiúsculas iguais, indicam diferença não significativa entre os grupos num mesmo } \\
\text { dia }(p>0,05) \text {. Nas linhas, letras minúsculas diferentes, indicam diferença significativa entre os dias num } \\
\text { mesmo grupo }(p<0,05) \text {. }\end{array}$} \\
\hline
\end{tabular}


o efeito da suplementação com crômio orgânico não foi imediato, pois foi necessário suplementar os bovinos por 60 dias para a manifestação do seu efeito, ou seja, para elevar a concentração sérica de crômio (tabela I). Ainda, no presente estudo os animais não apresentaram, em momento algum, qualquer sinal clínico de intoxicação por crômio.

\section{BIBLIOGRAFIA}

Bryan, M.A., Socha, M.T. and Tomlinson, D.J. 2004. Supplementing intensively grazed lategestation and early-lactation dairy cattle with chromium. J. Dairy Sci., 87: 4269-4277.

Carvalho, F.A.N., Barbosa, F.A. and McDowell, L.R. 2003. Minerais. In: Carvalho, F.A.N, F.A. Barbosa and L.R. McDowell (eds.). Nutrição de bovinos a pasto. PapelForm Editora Ltda. Belo Horizonte. pp. 157-368.

Giometti, J., Chiacchio, S.B., Albas, A., Pardo, P.E., Bremer-Neto, H., Giometti, A.I. e Reis, L.S.L.S. 2006. Influência da suplementação com crômio na resposta imune humoral anti-rábica em bovinos. Arq. Inst. Biol., 73: 421-427.

Hayirli, A., Bremmer, D.R., Bertics, S.J., Socha,
Conforme as condições experimentais e os resultados obtidos permitiram concluir que: a levedura de $\mathrm{Cr}$ pode ser utilizada como fonte deste elemento mineral para os bovinos e a suplementação com 2,38 mg/ bovino/dia foi a dose que mais elevou a concentração que sérica de $\mathrm{Cr}$ nos bovinos da raça Nelore durante o período experimental.

M.T. and Grummer, R.R. 2001. Effect of chromium supplementation on production and metabolic parameters in periparturient dairy cows. $J$. Dairy Sci., 84: 1218-1230.

Mordenti, A., Piva, A. and Piva, G. 1997. The European perspective on organic chromium in animal nutrition. In: Lyons, T.P., Jacques, K.A. $13^{\text {th }}$ Alltech's Annual Symposium. Biotecnololgy in the feed industry. Un.Press. Notthingham.

NRC. 1996. National Research Council. Minerals. In: National Research Council (ed). Nutrient requerements of beef cattle. National Academy Press. Washington. pp. 54-74.

Zar, J.H. 1999. Biostatistical Analysis. $4^{a}$ ed. Prentice Hall. New Jersey. 